\title{
In Vitro Rumen Fermentation and Anti Mastitis Bacterial Activity of Diet Containing Betel Leaf Meal (Piper betle L.)
}

\author{
A. A. Yamin, A. Sudarman*, \& D. Evvyernie \\ Department of Animal Nutrition and Feed Technology, Faculty of Animal Science, \\ Bogor Agricultural University \\ Jln. Agatis, Kampus IPB Darmaga, Bogor 16680, Indonesia \\ (Received 26-03-2013; Reviewed 29-04-2013; Accepted 18-07-2013)
}

\begin{abstract}
The aims of this experiment was to study the inhibition effect of betel leaf meal (BLM) addition into concentrate diet on mastitis causing bacteria and on rumen fermentation condition. The study consisted of five dietary treatments of BLM level in concentrate feed, i.e., $0 \%, 2 \%, 4 \%, 6 \%$, and $8 \%$ and four replicates of each treatment. The treatment diets together with napier grass in ratio of 40 : 60 were fermented using rumen liquor. All treatments were examined their antibacterial activity before and after fermentation. After four hours fermentation, supernatant of each samples were analyzed for VFA, $\mathrm{NH}_{3}$ number of bacteria and protozoa. Dry matter (DM) and organic matter (OM) digestibility were analyzed after $48 \mathrm{~h}$ fermentation. The results showed that before fermentation, $8 \%$ BLM addition caused the bigest $(\mathrm{P}<0.05)$ inhibition diameter of Staphylococcus spp. growth compared to other lower levels. However after fermentation there were no significant differences among the addition levels of BLM. Two per cent of BLM addition produced higher VFA $(\mathrm{P}<0.05)$ than the other addition levels. Ammonia concentration, dry matter (DM) and organic matter (OM) digestibility were not different among the treatments. Addition of BLM significantly $(\mathrm{P}<0.01)$ decreased protozoa number, but did not affect bacterial count. It is concluded that the addition of $2 \%$ BLM in concentrate feed can be used effectively to inhibit the growth of mastitis causing bacteria (Staphylococcus spp.) and does not disturb rumen fermentation condition.
\end{abstract}

Key words: betel leaf, mastitis, rumen microbe, rumen fermentation, Staphylococcus spp.

\section{ABSTRAK}

Penelitian ini bertujuan untuk mengkaji pengaruh penambahan tepung daun sirih (Piper betle L.) dalam konsentrat terhadap bakteri penyebab mastitis dan kondisi fermentasi rumen. Penelitian ini terdiri atas lima perlakuan pakan $(0 \%, 2 \%, 4 \%, 6 \%$, dan $8 \%$ level tepung daun sirih dalam konsentrat) dan empat ulangan. Pakan perlakuan beserta rumput gajah dengan perbandingan $40: 60$ kemudian difermentasi menggunakan cairan rumen. Aktivitas antibakteri sebelum dan setelah difermentasi diuji pada setiap perlakuan. Setelah empat jam fermentasi, supernatan setiap sampel diambil untuk pengujian VFA, $\mathrm{NH}_{3}$, total bakteri dan protozoa. Selanjutnya, KCBK dan KCBO dianalisis setelah 48 jam. Hasil penelitian ini menunjukkan bahwa sebelum difermentasi semakin tinggi level tepung daun sirih (dari $0 \%$ sampai $8 \%$ ) mengakibatkan diameter hambat yang semakin luas $(P<0,05)$ terhadap pertumbuhan Staphylococcus spp. Namun setelah difermentasi tidak terdapat perbedaan nyata di antara level daun sirih. Hasil fermentasi in vitro menunjukkan bahwa level tepung daun sirih berpengaruh nyata $(P<0,01)$ terhadap VFA, tetapi tidak berpengaruh nyata terhadap konsentrasi $\mathrm{NH}_{3}$ KCBK, dan KCBO. Level tepung daun sirih nyata menurunkan $(\mathrm{P}<0,01)$ populasi protozoa, tetapi tidak berpengaruh nyata terhadap total bakteri. Dapat disimpulkan bahwa penambahan $2 \%$ tepung daun sirih dalam konsentrat dapat digunakan sebagai penghambat pertumbuhan bakteri penyebab mastitis dan tidak mengganggu kondisi fermentasi rumen.

Kata kunci: daun sirih, mastitis, fermentasi rumen, mikroba rumen, Staphylococcus spp.

*Corresponding author:

E-mail: a_sudarman@yahoo.com 


\section{INTRODUCTION}

In 2004, subclinical mastitis prevalence in Indonesia was recorded for $65 \%-75 \%$ and it continuously increased to $75 \%-83 \%$ in 2006 (Sudarwanto \& Sudarnika, 2008) with a decreasing of milk production about $70 \%$. This indicates that eradication and prevention of subclinical mastitis program have not been applied well by the farmers and other stake holders. Mastitis causes a great economic loss such as treatment cost, veterinary time and consultation fees, cost of the drugs, discarded milk, labour cost, fatality, repeated cases of mastitis, decrease in milk yield, milk quality changes, decreased hygienic quality of milk and public health considerations, culling and replacement cost, premium loss and penalties, and post-milking teat disinfection (Seegers et al. 2003; Shim et al. 2004; Rodrigues et al. 2005; Petrovski et al. 2006). Antibiotic is usually used for treating and preventing through teat dipping after each milking. However using antibiotic is hazardous for consumer health and it is worldwide refused due to residues appearance in milk and risk factor in creating resistant strain of bacteria. Therefore, natural product which harmless to consumer such as betel leaf is needed to replace role of antibiotic.

Betel leaf (Piper betle L.) was well known by Indonesian people as medicinal plant and has an immunity stimulant because it contains $4.2 \%$ of essential oil and most of them are chavicol paraallyphenol, a derivative of Chavica betel, betephenol as an isomer of euganol allypyrocatechine, cineol methil euganol, caryophyllen, kavikol, kavibekol, estragol, and terpinen (Sastroamidjojo, 1997). Some of empirical and scientific studies about antibacterial content of betel leaf leaded us to its potential to be used as feed additive for dairy cow and expected to inhibit and kill various bacteria particularly bacteria which cause mastitis such as Staphylococcus sp. or Streptococcus $s p$. Previous research of the efficacy of betel leaves extract for teat dipping given after milking showed that Piper betle leaves extract have ability to reduce the number of bacteria in milk of mastitis suffered cows (Poeloengan et al., 2005).

Some herbs were used as the sources of antibacterial compounds and effectively decreased microorganism population at in vitro fermentation (Pattnaik et al., 1996). Wallace et al. (2002) reported that essential oil contained in herbal leaves did not influence volatile fatty acids (VFA) production, $\mathrm{NH}_{3}$ concentration, protozoa number, and microbial protein flow in rumen. Up to know, betel leaf extract has not ever been used yet as a feed supplement in ruminant ration. This experiment aimed to elaborate the use of betel leaf as anti mastitis feed supplement through in vitro study.

\section{MATERIALS AND METHODS}

The experiment was divided into 3 stages; 1) Antibacterial activity test of betel leaf meal before and after incubation with rumen fluid, 2) Effect of betel leaf meal on rumen fermentability and digestibility, and 3) Effect of betel leaf meal on viability of rumen microorganism.

\section{Antibacterial Activity Test}

Antibacterial activity consisted of 5 treatments of betel leaf level $(0 \%, 2 \%, 4 \%, 6 \%$, and $8 \%$ in feed concentrate mixed with elephant grass). Staphylococcus sp. bacteria was cultured in blood agar media and incubated at $37^{\circ} \mathrm{C}$ for $24 \mathrm{~h}$. Colonies formed were removed by sterile ose into a reaction tube which contained $5 \mathrm{~mL}$ of phosphate buffer solution (PBS), then incubated at $37{ }^{\circ} \mathrm{C}$ for $2 \mathrm{~h}$ until turbidity was equal with McFarland 1 standard ( $\left.3 \times 10^{8} \mathrm{cfu} / \mathrm{mL}\right)$. Then, betel leaf meal was mixed with dairy concentrate feed before diluted in 5 $\mathrm{mL}$ distillated water and dropped onto a paper disc on agar media. After $4 \mathrm{~h}$ in vitro fermentation, rumen fluid filtered and dropped onto a paper disc and incubated at $37^{\circ} \mathrm{C}$ for $24 \mathrm{~h}$. Parameter observed was diameter of clear zone formed on agar media.

\section{In Vitro Fermentation Test}

The effect of BLM was evaluated in an in vitro batch fermentation (Tilley \& Terry, 1963) trial using a concentrate feed containing betel leaf at levels of $0 \%$, $2 \%, 4 \%, 6 \%$, and $8 \%$ and napier grass as fiber source in ratio of 40:60. Cattle rumen fluids were collected from a slaughter house using warm $\left(39^{\circ} \mathrm{C}\right)$ thermos which was previously filtered using cheese cloth. Incubations were conducted in $90 \mathrm{~mL}$ tube containing $10 \mathrm{~mL}$ of rumen fluid, $40 \mathrm{~mL}$ of McDougall ( $\mathrm{pH} \mathrm{8-8.3)} \mathrm{and} 0.5 \mathrm{~g}$ of the experimental diet per tube. Each tube was gassed with $\mathrm{CO}_{2}$ before sealing with rubber corks with gas release valve. Treatments were tested at an initial $\mathrm{pH}$ of 7.0. Incubations were conducted in a water bath at 39 ${ }^{\circ} \mathrm{C}$ for $4 \mathrm{~h}$ for antibacterial activity, VFA, $\mathrm{NH}_{3}$, number of bacteria and protozoa. To analyze DM and OM digestibility, incubations were conducted for $48 \mathrm{~h}$.

After $4 \mathrm{~h}$ incubation, $\mathrm{HgCl}_{2}$ was added 2-3 drops to kill the rumen microbes and centrifuged at $4000 \mathrm{rpm}$ for $15 \mathrm{~min}$. Liquid samples were withdrawn from each tube to determine $\mathrm{pH}$ and analyze ammonia N (Conway 1958) and total VFA concentrations using steam distillation method. Ammonia concentration analysis was initialed with lubricating the Conway using vaseline.

\section{In Vitro Digestibility}

After $48 \mathrm{~h}$ incubation DM and OM digestibility were determined (Tilley \& Terry, 1963). The fermentor's tube rubber corks were unsealed. Saturated mercury chloride $(\mathrm{HgCl})$ was added 2-3 drops to kill microbe and centrifuged $4000 \mathrm{rpm}$ for $10 \mathrm{~min}$ to separate sediment and supernatant. Supernatants were discarded and centrifuged $4000 \mathrm{rpm}$ for $15 \mathrm{~min}$. $50 \mathrm{~mL}$ of $\mathrm{HCl}$-pepsin solution $0.2 \%$ added and incubated again for $48 \mathrm{~h}$ without rubber corks. Residues were filtered with filter paper (Whatman No. 41) and enamel cup which was already known weight using vacuum pump. Filtrates were placed in the porcelain dish and dried to analyze dry matter in the oven at $105{ }^{\circ} \mathrm{C}$ for $24 \mathrm{~h}$ for determining DM. Filtrates were ashed at $450-600{ }^{\circ} \mathrm{C}$ for $8 \mathrm{~h}$ in electrical furnish for determining OM digestibility. 
Fermentation residues were used without samples as a blanco. Dry and organic matter digestibility were then calculated.

\section{Viability Test of Bacteria and Protozoa}

Bacterial population was determined by counting the viable bacterial colonies (Ogimoto \& Imai, 1981). Brain Heart Infusion (BHI) media was used to count total bacteria. Brain Heart Infusion was made by mixing such as $3.7 \mathrm{~g}$ of BHI powder, $0.05 \mathrm{~g}$ of glucose, $0.05 \mathrm{~g}$ of sellulobiose, $0.05 \mathrm{~g}$ of starch, $0.05 \mathrm{~g}$ of cystein, $100 \mu \mathrm{L}$ of hemin, $0.005 \mathrm{ml}$ of resazurin and $1.5 \mathrm{~g}$ of agar and then stored in sterile tube. The mixture was heated until the color changed from yellowish brown to reddish brown and changed back to yellowish brown. Then it was chilled and flowed by $\mathrm{CO}_{2}$ Anaerobe BHI media was stored in hungate tube which previously was filled with $0.150 \mathrm{~g}$ of bacto agar until the volume reached $4.9 \mathrm{~mL}$ of each tube. Rumen fluid which had been treated and incubated for four hours was pipetted for $0.05 \mathrm{~mL}$ and mixed with $4.95 \mathrm{~mL}$ dilution media. This was repeated to form serial dilutions $\left(10^{-2} 10^{-4}, 10^{-6}, 10^{-8}\right)$. Each dilution tube was then taken $0.1 \mathrm{~mL}$ and mixed in agar media and rolled while it was given water in the roller until became solid form. Then bacteria were incubated for $24 \mathrm{~h}$ and each colony was counted at the tube using marker.

For protozoa counting (Ogimoto \& Imai, 1981), 1 $\mathrm{mL}$ of rumen fluid samples were taken immediately after $4 \mathrm{~h}$ incubation and stored in sample bottles which had been filled $1 \mathrm{~mL}$ of tryphan blue formaline Saline (TBFS). Rumen fluid was taken using syringe and injected between counting chamber and cover glass. Direct counts of total bacteria were made using a cell chamber (0.0625 mm², $0.02 \mathrm{~mm}^{2}$ deep; Brand, Germany) under light microscope (Olympus Optical Co., Japan).

\section{Statistical Analysis}

Data obtained were analyzed using analysis of variance (ANOVA). Antibacterial activity data were analyzed according to completely randomized design, and VFA, $\mathrm{NH}_{3}, \mathrm{DM}$, and DO digestibility, number of bacteria and protozoa were analyzed according to block randomized designs. Differences between means were tested using the Duncan multiple range test and declared at $\mathrm{P}<0.05$ (Gasperz, 1994).

\section{RESULTS AND DISCUSSION}

\section{Antibacterial Activity of Betel Leaf Meal on Staphylococcus sp.}

Antibacterial activity test of BLM with level $0 \%$, $2 \%, 4 \%, 6 \%$, and $8 \%$ of concentrate diet on Staphylococcus $s p$. resulted in inhibition diameter zone of $0.0,3.9,15.9$, 18.1, and $22.0 \mathrm{~mm}$, respectively. The high inhibition diameter associated with the high levels of BLM in concentrate diet. Inhibition diameter occurred due to bioactive compounds contained in BLM which had an- tibacterial activity. BLM treatments significantly $(\mathrm{P}<0.05)$ inhibited Staphylococcus sp. before in vitro fermentation (Table 1). This in line with the report of Poeloengan et al. (2005) that Piper betle leaves in concentration of $50 \%$; $25 \% ; 12.5 \%$; and $6.25 \%$ have an antibacterial effect on Streptococcus agalactiae, Staphylococcus aureus dan Staphylococcus epidermidis. Benchaar et al. (2008) found that carvacrol contained within essential oil could kill Staphylococcus aureus and Pseudomonas aeruginosa. However, after in vitro fermentation, all addition levels of BLM showed higher $(\mathrm{P}<0.05)$ inhibition compared to control $(0 \%)$ (Table 1$)$, but did not different among addition levels $(2 \%-8 \%)$. This similar response might occurred due to the adaptation of rumen bacteria to the high level of BLM. Adaptable bacteria can reduce the activity of essential oil after rumen fermentation because the bacteria degraded the high level of BLM. However, when the BLM was given in low and medium levels, it could stimulate rumen bacteria and increased the antibacterial activity of BLM after fermentation (Acamovic \& Brooker, 2005; Patra \& Yu, 2012). McIntosh et al. (2003) reported the list resistantcy and sensitivity of bacteria to essential oil-containing media, Streptococcus bovis was the most resistant bacteria while Prevotella ruminicola, Clostridium sticklandii, and Peptostreptococcus anaerobius were the most sensitive and Prevotella bryantii adapted to grow in media containing high concentration of essential oil. High level addition of BLM was related to the presence of the adaptable bacteria such as Prevotella bryantii.

\section{VFA Production}

Betel leaf meal addition resulted $(\mathrm{P}<0.01)$ in the variation of total VFA among treatments. Total VFA production were higher $(\mathrm{P}<0.05)$ for the diet containing $2 \%$ of BLM than those of diet with higher level of BLM addition $(4 \%, 6 \%$, and $8 \%$ ) and control diet (Figure 1). Control diet and BLM addition of $2 \%, 4 \%, 6 \%$, and $8 \%$ had similar total VFA production.

Decreasing VFA production at $4 \%, 6 \%$, and $8 \%$ dietary BLM treatments were due to the increase in bioactive compounds in the diets, one of which was eugenol which had antibacterial activity (Benchaar et al., 2007). Benchaar et al. (2008) reported that high doses of antibac-

Table 1. Inhibition zone diameter of betel leaf meal (BLM) on Staphylococcus sp.

\begin{tabular}{ccccc}
\hline \multicolumn{2}{c}{ Before ruminal fermentation } & & \multicolumn{2}{c}{ After ruminal fermentation } \\
\cline { 1 - 2 } \cline { 5 - 6 } $\begin{array}{c}\text { BLM level } \\
(\%)\end{array}$ & $\begin{array}{c}\text { Inhibition } \\
\text { diameter }(\mathrm{mm})\end{array}$ & & $\begin{array}{c}\text { BM level } \\
(\%)\end{array}$ & $\begin{array}{c}\text { Inhibition } \\
\text { diameter }(\mathrm{mm})\end{array}$ \\
\hline 0 & $0.00 \pm 0.00^{\mathrm{a}}$ & & 0 & $0.00 \pm 0.00^{\mathrm{a}}$ \\
2 & $3.90 \pm 3.62^{\mathrm{a}}$ & & 2 & $16.10 \pm 1.92^{\mathrm{b}}$ \\
4 & $15.90 \pm 3.64^{\mathrm{b}}$ & & 4 & $15.30 \pm 1.64^{\mathrm{b}}$ \\
6 & $18.10 \pm 1.40^{\mathrm{bc}}$ & & 6 & $15.80 \pm 1.14^{\mathrm{b}}$ \\
8 & $22.00 \pm 2.88^{\mathrm{c}}$ & & 8 & $14.60 \pm 0.87^{\mathrm{b}}$ \\
\hline
\end{tabular}

Note: Means in the same column with different superscripts differ significantly $(\mathrm{P}<0.05)$. 


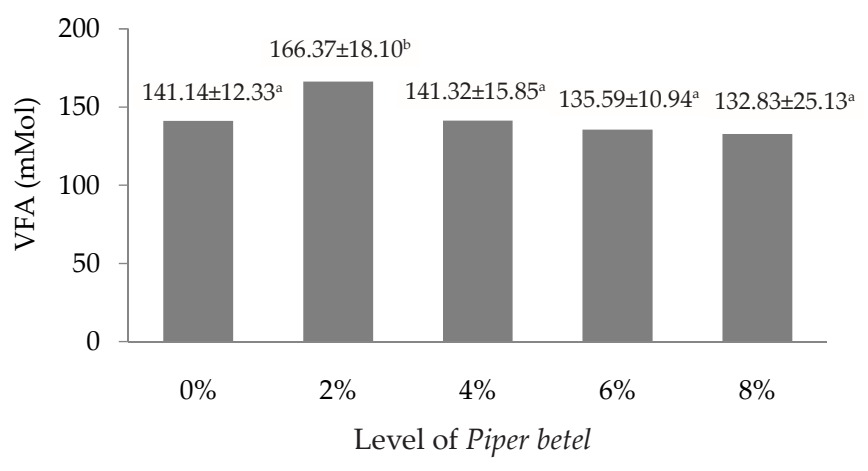

Figure 1. Total VFA concentration resulted in in vitro fermentation from elephant grass and feed concentrate added with different level of betel leaf meal

terial compounds of BLM did not affect total VFA. On the other hand, Castillejos et al. (2006) reported that eugenol decreased concentration of total VFA and change VFA profile but increased propionate concentration.

High doses of bioactive compounds contained in BLM changed rumen ecology by inhibiting fibrolytic bacteria in particular Fibrobacter succinogenes and Ruminococcus flavefaciens resulting in low fermentation product (Lin et al., 2012). Total VFA production as response to the addition of BLM varied according to the addition level of BLM. High level of BLM addition decreased rumen population of bacteria. On the other hand low level of BLM addition modulated the bacteria growth led to high VFA production. The result suggested that low level of BLM in the diet may improve ruminal fermentation characteristics.

\section{$\mathrm{NH}_{3}$ Concentration}

$\mathrm{NH}_{3}$ production in vitro as the response to dietary addition of BLM were shown in Figure 2. Dietary addition of BLM did not significantly affect $\mathrm{NH}_{3}$. Different BLM addition levels produced statistically similar $(\mathrm{P}>0.05) \quad \mathrm{NH}_{3}$ concentration. However, there was a tendency that $2 \%$ of BLM addition had higher $\mathrm{NH}_{3}$ concentration compared to those of control and other levels of BLM addition. Eventhough Benchaar et al. (2008)

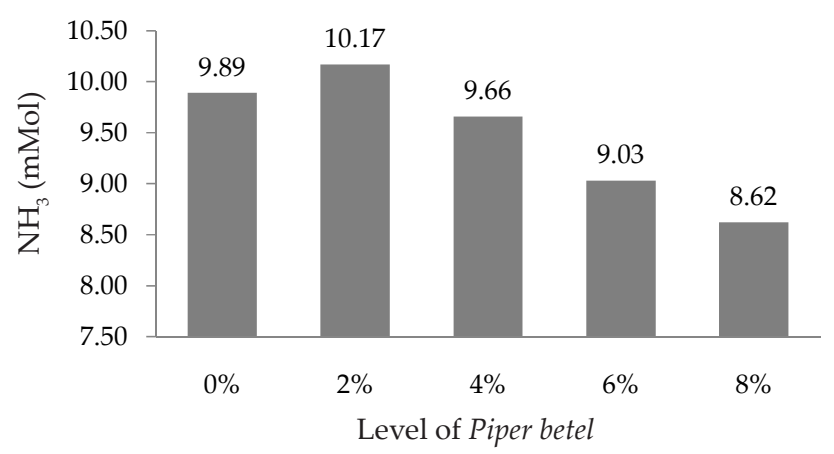

Figure 2. $\mathrm{NH}_{3}$ concentration resulted in in vitro fermentation from elephant grass and feed concentrate added with different level of betel leaf meal reported that chemical composition and dose of essential oil affect $\mathrm{N}$ metabolism in rumen, but in the present result the difference was not significant. Ammonia is the main nitrogen sources of microbes to synthesize amino acid (Sitoresmi et al., 2009) for their growth. Factor affecting the reduction of $\mathrm{NH}_{3}$ was low degradation of feed protein in rumen. The decrease of $\mathrm{NH}_{3}$ concentration and deaminase activity was due to the decrease of bacteria growth, in particular hyper-ammonia production (HAP) bacteria (Russell \& Houlihan, 2003; Patra \& Yu, 2012). Wallace (2002), reported that Prevotella spp. and Ruminobacter amylophilus were HAP bacteria and most sensitive to essential oil whereas they have ability to produce high ammonia from amino acid sources. On the other hand, a decrease in feed protein degradation by essential oil would increase the by-pass of protein and thus increase the total protein supply to ruminant (Lin et al., 2012).

\section{Dry and Organic Matter Digestibility}

Dry and organic matter digestibility were not significantly different among the treatments (Table 2). Dry and organic matter digestibility results had similar pattern with that of $\mathrm{NH}_{3}$ concentration data, i.e., there was a tendency that $2 \%$ of BLM addition had higher dry and organic matter digestibility concentration compared to those of control and other levels of BLM addition.

The same results were reported by Castillejos et al. (2006) that eugenol had no effect on DM, OM, NDF, and ADF digestion. Patra \& Yu (2012) also reported that dry matter and NDF degradability were not affected by essential oil, but it would decrease DM digestibility in high doses. It appears that addition of BLM had not negative effect on rumen degradability especially in low doses.

\section{Rumen Microorganism and Rumen $\mathrm{pH}$}

Total viable bacteria were not affected by BLM addition (Table 3). The present results were lower than the results of Koike \& Kobayashi (2009) who reported that the total bacteria were $10^{10}-10^{11}$ per $\mathrm{mL}$ of rumen content. The contrary results were reported by Patra \& Yu (2012) that essential oil use increased bacteria at low and medium doses, but it tended to decrease bacteria at high doses. This was further explained by Acamovic \& Brooker (2005) who reported that secondary metabolite such as essential oil could interact to various cell components which modulate the response of their targets. Therefore, BLM addition in low level could stimulate the

Table 2. In vitro digestibility with different level of betel leaf meal (BLM) at in vitro fermentation

\begin{tabular}{lccccc}
\hline \multirow{2}{*}{$\begin{array}{l}\text { In vitro } \\
\text { digestibility }\end{array}$} & \multicolumn{5}{c}{ Level of BLM (\%) } \\
\cline { 2 - 6 } & 0 & 2 & 4 & 6 & 8 \\
\hline $\mathrm{DM}, \%$ & 48.65 & 53.21 & 51.54 & 52.67 & 50.78 \\
$\mathrm{OM}, \%$ & 46.79 & 51.79 & 50.38 & 51.10 & 49.79 \\
\hline
\end{tabular}


Table 3. $\mathrm{pH}$, number of bacteria, and protozoa of different level of betel leaf meal (BLM) at in vitro fermentation

\begin{tabular}{lccccc}
\hline \multirow{2}{*}{ Parameter } & \multicolumn{5}{c}{ Level of BLM (\%) } \\
\cline { 2 - 6 } & 0 & 2 & 4 & 6 & 8 \\
\hline $\mathrm{pH}$ & 6.7 & 6.7 & 6.7 & 6.7 & 6.7 \\
$\begin{array}{l}\text { Bacteria } \\
(\mathrm{cfu} / \mathrm{mL})\end{array}$ & $7.5 \times 10^{6}$ & $1.2 \times 10^{7}$ & $6.4 \times 10^{6}$ & $2.8 \times 10^{6}$ & $3.8 \times 10^{6}$ \\
$\begin{array}{l}\text { Protozoa } \\
\text { (cfu/mL) }\end{array}$ & $2.3 \times 10^{5 \mathrm{a}}$ & $7.9 \times 10^{4 \mathrm{~b}}$ & $8.3 \times 10^{4 \mathrm{~b}}$ & $5.5 \times 10^{4 \mathrm{~b}}$ & $4 \times 10^{4 \mathrm{~b}}$ \\
\hline
\end{tabular}

Note: Means in the same column with different superscripts differ significantly $(\mathrm{P}<0.05)$

number of rumen bacteria. The present result showed that level of $2 \%$ of BLM addition had slightly higher rumen bacteria than control and other addition levels, but the difference was not strong enough.

The effect of BLM addition on number of protozoa is shown in Table 3. Addition of BLM significantly $(\mathrm{P}<0.01)$ decreased number of protozoa. The increase BLM level decreased linearly protozoa. The decrease of protozoa approved that BLM contained the chemical compound which was toxic to the protozoa. Defaunation already became object of research of microbiologist several years ago (Wallace et al. 2002). Lin et al. (2012), reported that essential oil combination would decrease $50 \%-90 \%$ of protozoa and fungi. It showed that BLM can be utilized as a defaunating agent. Furthermore, it is expected that methane production could be reduced with the addition BLM in concentrate diet, since methanogenic bacteria were associated with protozoa.

Rumen $\mathrm{pH}$ of each treatment was similar, i.e., 6.7 (Table 3) indicating that rumen $\mathrm{pH}$ was unaffected by BLM addition. This $\mathrm{pH}$ value supported a conducive environment for growth of rumen microbes. The same results were reported by Lin et al. (2012) that essential oil type and dose did not affect rumen $\mathrm{pH}$.

\section{CONCLUSION}

Betel leaf meal addition in concentrate diet has antibacterial activity on mastitis causing bacteria (Staphylococcus spp.) either before or after in vitro fermentation. Two per cent addition of BLM in concentrate diet has the optimum effect on VFA production, $\mathrm{NH}_{3}$ concentration, dry matter and organic matter digestibility, and number of bacteria and protozoa.

\section{ACKNOWLEDGMENT}

This experiment was funded by Directorate General of Higher Education, Ministry of Education and Culture, Republic of Indonesia through National Strategy Grant of FY 2012 No. 046/SP2H/PL/Dit.Litabmas/III/2012.

\section{REFERENCES}

Acamovic, T. \& J. D. Brooker. 2005. Biochemistry of plant secondary metabolites and their effects in animals. Proc. Nutr.
Soc. 64: 403-412. http://dx.doi.org/10.1079/PNS2005449

Benchaar, C., A. V. Chaves, G. R. Fraser, Y. Wang , K. A. Beauchemen, \& T. A. McAllister. 2007. Effects of essential oils and their components on in vitro rumen microbial fermentation. Can. J. Anim. Sci. 87: 413-419. http://dx.doi. org/10.4141/CJAS07012

Benchaar C., S. Calsamiglia, A. V. Chaves, G. R. Fraser, D. Colombotto, T. A. McAllister, E K. A. Beauchemen. 2008. A Review of plant-derived essential oils in ruminant nutrition and production. Anim. Feed Sci. Tech. $145: 209-228$. http://dx.doi.org/10.1016/j.anifeedsci.2007.04.014

Castillejos, L. S., Calsamiglia, \& A. Ferret. 2006. Effect of essential oil active compounds on rumen microbial fermentation and nutrient flow in in vitro systems. J. Dairy. Sci. 89: 26492658. http://dx.doi.org/10.3168/jds.S0022-0302(06)72341-4

Conway, E. J. 1958. Microdiffusion Analysis and Volumetric Error. Macmillan Publishing Co.

Gaspersz, V. 1994. Metode Perancangan Percobaan: Untuk Ilmu-Ilmu Pertanian, Ilmu-Ilmu Teknik, dan Biologi. CV. Armico, Bandung.

Koike, S. \& Y. Kobayashi. 2009. Fibrolytic rumen bacteria: their ecology and functions. Asian-Aust. J. Anim. Sci. 22: 131138.

Lin, B., Y. Lu, J. H. Wang, Q. Liang, \& J. X. Liu. 2012. The effects of combined essential oils along with fumarate on rumen fermentation and methane production in vitro. J. Anim. Feed Sci. 21: 198-210.

McDougall, E. I. 1948. Studies on ruminant saliva. 1. The compand output of sheep's saliva. Biochem. J. 43:99-109.

McIntosh, F. M., P. Williams, R. Losa, R. J. Wallace, D. A. Beever, \& C. J. Newbold. 2003. Effects of essential oils on ruminal metabolism microorganisms and their protein. Appl Environ Microbiol. 69: 5011-5014. http://dx.doi. org/10.1128/AEM.69.8.5011-5014.2003

Ogimoto, K. \& S. Imai. 1981. Atlas of Rumen Microbiology. Japan Scientific Societies Press, Tokyo.

Patra, A. K. \& Yu Z. 2012. Effect of essential oil on methane production, fermentation, abundance and diversity rumen microbial population. Appl. Environ. Microbiol. 12 : 42714280. http://dx.doi.org/10.1128/AEM.00309-12

Pattnaik, S. V. R., Subramanyam, \& C. Kole. 1996. Antibacterial and antifungal activity of ten essential oils in vitro. Microbios. 86:237-246.

Petrovskia, K.R., M. Trajcevb \& G. Buneski. 2006. A review of the factors affecting the costs of bovine mastitis. Tydskr. S. Afr. vet. Ver. 77: 52-60

Poeloengan, M., M. N. Susan, \& Andriani. 2005. Efficacy of Piper betle Linn toward subclinical mastitis. Seminar Nasional Teknologi Peternakan dan Veteriner. Pp. 1015-1019.

Rodrigues, A. C. O., D. Z. Caraviello, \& P. L. Ruegg. 2005. Management of Wisconsin dairy herds enrolled in milk quality teams. J. Dairy Sci. 88: 2660-2671. http://dx.doi. org/10.3168/jds.S0022-0302(05)72943-X

Russell, J. B. \& A. J. Houlihan. 2003. Ionophore resistance of ruminal bacteria and its potential impact on human health. FEMS Microbiol. Rev. 27: 65-74. http://dx.doi.org/10.1016/ S0168-6445(03)00019-6

Sastroamidjojo, S. 1997. Obat Asli Indonesia. Dian Rakyat, Jakarta.

Seegers, H. C., Fourichon, \& F. Beaudeau. 2003. Production effects related to mastitis and mastitis economics in dairy cattle herds. Vet. Res. 34: 475-491. http://dx.doi.org/10.1051/ vetres:2003027

Shim E. H., R. D. Shanks, \& D. E., Morin. 2004. Milk loss and treatment costs associated with two treatment protocols for clinical mastitis in dairy cows. J. Dairy. Sci. 87: 27022708. http://dx.doi.org/10.3168/jds.S0022-0302(04)73397-4 
Sitoresmi, P. D., L. M. Yusiati, \& H. Hartadi. 2009. Pengaruh penambahan minyak kelapa, minyak biji bunga matahari, dan minyak kelapa sawit terhadap penurunan produksi metan di dalam rumen secara in vitro. Buletin Peternakan 33: 96-105.

Sudarwanto, M. \& E.Sudarnika. 2008. Hubungan antara pH susu dengan jumlah sel somatik sebagai parameter mastitis subklinik. Med. Pet. 31:107-113.
Tilley, J. M. A. \& R. A. Terry. 1963. A. two stage technique for the in vitro digestion of forage crop. Journal of British Grassland. 18: 104-111. http://dx.doi.org/10.1111/j.13652494.1963.tb00335.x

Wallace, R. J., N. R. McEwan, F. M. McIntosh, B. Teferedegne, \& C. J. Newbold. 2002. Natural product as manipulators of rumen fermentation. Asian-Aust. J Anim Sci.15: 14581468. 